\title{
The Relationship between Good Readers' Attention, Reading Fluency and Reading Comprehension
}

\author{
Mustafa Yildiz, Ezgi Çetinkaya* \\ Department of Elementary Education, Faculty of Education, Gazi University, Turkey
}

Copyright $\subset 2017$ by authors, all rights reserved. Authors agree that this article remains permanently open access under the terms of the Creative Commons Attribution License 4.0 International License

\begin{abstract}
This study aimed to examine the relationship between fourth-graders' reading fluency, reading comprehension and attention. It was conducted using the relational screening model and included 132 fourth-graders with grade level adequate reading skills. The study results showed that good readers' attention had significant effects on reading speed, prosody, word recognition and comprehension, respectively. There is also a higher level of relationship between attention, reading speed and prosody. To improve good readers' prosodic reading skills and increase their reading speeds, attention-enhancing activities are needed.
\end{abstract}

Keywords Attention, Fluency, Comprehension, Reading Speed, Prosody, Word Recognition

\section{Introduction}

Limited by our capabilities, attention is the process of selecting some of many potential sensory inputs [19]. Attention ensures that knowledge is transferred from sensory memory to short-term memory to carry out further processing, and that it is noticed and selected during this transfer. When learning letters, children acquaint themselves with their different characteristics to distinguish them from each other. For example, to distinguish " $b$ " from " $d$ " they not only pay attention to the presence of a line adjacent to the circle, but also to the location of the vertical line on its right or left side [19]. This is also an important hint about the role of attention in letter recognition, which is a basic reading process.

Attention is a prerequisite for learning. It can be categorized as focused attention, sustainable attention, selective attention and divided attention [7, 25]. This study mainly focuses on sustainable attention. Sustainable attention is the type of attention that provides the ability to focus on a task for a long time [18]. It is required to analyze the sentences in reading material [3] and to utilize them actively at different times $[4,20]$. Therefore, it is crucial for reading skill. Students with inadequate sustainable attention will probably fail to accomplish the tasks assigned to them [24].

Reading is a complex process that is affected by several factors. According to the automatization theory of LaBerge and Samuels (1974), attention is a prerequisite both for reading fluency and reading comprehension. Efficient reading requires sustainable attention since it provides an active preparation process during which the reader aims to read the text fully. Sustainable attention is the ability to direct attention to a subject and focus on a specific goal for even a long period of time [4]. It also facilitates the improvement of cognitive text comprehension [21].

Difficulty in reading and distraction lead to poor reading skills in the early years of learning [8]. Both Perfetti's verbal efficiency theory and LaBerge and Samuels' limited attention model suggest that the attention span required for reading is limited to the extent of attention used by the individual during the process of word recognition. To have superior comprehension, unused processing memory should be capable of rapid and accurate word recognition. This theory suggests that inadequately talented readers recognize the printed words more slowly, and understand later than those who are talented [8]. Furthermore, those who have poor ability to recognize words can also be inadequate in the mechanism of controlling attention, which negatively affects reading skills [4]. Thus, poor readers have difficulty in expressing their thoughts as a result of the inadequate attention control [4].

The attention that affects reading comprehension is also associated with reading fluency. Reynolds and Besner [17] suggest that attention has an important place in reading fluency since it plays a significant role in transforming written language materials into the spoken language. Wolf et al. [26] defined reading fluency: "Reading fluency is associated with the accuracy of word recognition and the ease of word recognition. It also involves accurate and smooth reading with proper prosody. In reading fluency, attention is distinguished from reading comprehension." 
This definition associates comprehension with automatization. The more reading is automatized, the less mental effort and attention are required for word recognition and reading accuracy. Therefore, attention can be directed to text comprehension.

Another study examined the relationship between sustainable attention and reading comprehension, and reported that attention and executive memory play an important role in reading comprehension skills. Children with attention deficit hyperactivity disorder (ADHD) have difficulty in these areas, and thus have problems with reading comprehension skills [22]. An earlier study by Rabiner [16] included children with no attention deficit and hyperactivity disorders (with normal development). In this study, the researcher observed a group of students from kindergarten through fifth grade. The study found that students who were considered by their kindergarten teachers to be more inattentive than the other students were obviously less successful in reading when they reached the fifth grade. The underachieving students' problems were caused by attention maintenance disorders.

There are no studies in the literature that examine attention states along with the reading fluency and reading comprehension of students with grade level adequate reading skills who are identified as good readers. Grade level adequate readers refer to children who can read and comprehend the materials that are suitable for their levels without the need for help from a teacher or an adult [2]. The present study is intended to reveal the relationship between attention, reading fluency and reading comprehension levels of fourth-grade students with grade level adequate reading skills whose word recognition levels are over $90 \%$. For this purpose, the following questions were asked:

1. What kind of a relationship is there between good readers' attention, reading speed, word recognition and reading comprehension?

2. To what extent do good readers' attention levels account for the levels of their reading speed, word recognition and reading comprehension?

\section{Method}

\subsection{Research Model}

The research was conducted using the correlational design [7] that allows for scanning types of comparison and correlation. The researchers tested the relationships between the scores obtained by each individual and determined the variables' ability to predict each other using correlational analyses.

\subsection{Study Group}

The study group was formed determining reading fluency levels of 141 fourth-graders in the school where the study was conducted and including students whose word recognition levels are over $90 \%$ in the study. The study group included 132 fourth-graders in a public school in the Yenimahalle district of the Ankara province. Of them, 72 were female, and 60 were male. Most of the participants were from families of moderate socioeconomic status considering the school location.

\subsection{Data Collection Tools}

\subsubsection{The Bourdon Attention Test}

This study used the Bourdon Attention Test to measure attention. This test was developed by Benjamin Bourdon in 1955. The Bourdon test is composed of two forms. The first involves picking certain letters from mixed typescripts and marking them, and the second involves picking certain figures from mixed typescripts and marking them [13]. The Bourdon Attention Test was chosen because it has frequently been used in previous studies conducted with primary school and higher level students $[1,10,13,5,24]$.

This test requires an interrupted attention orientation. There is no specified age limit for use of the test. However, children must have acquired the word recognition skills. There is no specified time limit. The test can be evaluated taking the time, number of correct or wrong answers into consideration. The practitioners can conduct evaluation by counting the number of children's correct answers in a specific period (e.g., five minutes). They can also count the number of correct letters or figures children are expected to mark. Alternatively, they can look into whether children have marked any letters or figures other than those that are required to be marked. No template has been formed. The practitioners can determine which letters or figures are required to be marked by themselves, and they can create their own templates [13].

\subsubsection{Measuring Reading Fluency}

Reading fluency was one of the variables in the research. It has three indicators: reading speed (the number of words read correctly per minute), word recognition (accuracy percentage) and prosody. The most widely used method for determining reading fluency levels is to determine the number of words read correctly in a minute [28]. Thus, the children were asked to read a fourth-grade level narrative text entitled "The Winter Season" (Annex 1), which they had not read beforehand.

Reading speed: This refers to the number of words read correctly in a minute. To determine reading speed, the number of reading errors was subtracted from the total number of words the students read in a minute. The study considered six types of reading errors reported by Akyol [2] (omission, insertion, repetition, inability to read, misreading and reversal).

Word recognition: The researchers used the Rasinsky and Padak's evaluation method (2003) to determine the students' word recognition levels. The number of words the students 
read correctly in a minute is divided by the total number of words they read and the resulting number is multiplied by 100 [28].

Prosody: This study examined the students' prosodic reading skills using the Multidimensional Fluency Scale, which was translated into Turkish by Yıldiz et al. [27]. This scale evaluates reading on four sub-scales: (1) expression and volume, (2) phrasing, (3) smoothness and (4) pace. Each sub-scale is worth 1-4 points, and scores range from 4-16.

\subsubsection{Measuring Reading Comprehension}

This research considered reading comprehension to be an implicit variable. The researchers used a comprehension test developed by Karasu [11]. The reading comprehension achievement test was prepared considering the learning acquisitions in the Turkish curriculum for fourth- and fifth-graders, the level determination exams conducted by the Ministry of National Education (MNE) and the questions on the international exams. The test comprised 25 multiple-choice questions that were created based on both narrative and expository texts since this type of question is considered to be the best measurer of the reading comprehension learning acquisitions. The grade level was taken into account, and the number of choices was limited to four. Correct answers are worth 1 point, and incorrect answers are worth 0 point, so scores range from $0-25$.

\subsection{The Data Collection Process}

The research data were collected in May 2016. The data collection process lasted three weeks. First, the researchers spoke with the principals of the school where the study would be conducted, informed them about the research and obtained their consent. Then, they spoke with the teachers of the fourth-graders and considering their opinions, they began to cooperate with the students with grade level adequate reading skills who were regarded to be good readers. The study was conducted with seven fourth-grade classes. In the first week, the researchers conducted the Bourdon Attention Test to determine attention span. The test was conducted with the aid of the school's guidance counselors. In the second week, the researchers worked to determine the reading fluency levels of the students. The readings were audiotaped in the school library to ensure a quiet and appropriate environment. The researchers listened to the students together and identified reading errors on a consensus basis. In the third week, the researchers conducted reading comprehension tests. Based on the results of the tests that were administered to 141 students, five students who were found to have levels of anxiety were excluded from the study. Afterwards, normal distribution analyses were conducted and based on their results, four more students were excluded from the study, which was continued with 132 students.

\subsection{Data Analysis}

During data analysis, the students' age and gender data along with their attention test, reading fluency test (reading accuracy, reading speed and prosody measurement) and reading comprehension test data were uploaded to SPSS software. Then, multiple regression analysis was conducted to determine which variable(s) affected each other. This analysis aimed to find the variable set that best identified the differences in the dependent variable.

\section{Findings}

This section presents the findings of the analyses. Table 1 shows the average and standard deviation values for attention, the components of reading fluency and reading comprehension.

Table 1. Descriptive Statistics for the Variables

\begin{tabular}{|c|c|c|c|c|c|c|}
\hline Variables & Min. & Max. & M. & SD & Kurto & Skew \\
\hline 1. Attention & 80.0 & 120.0 & 108.1 & 9.72 & .345 & -1.020 \\
\hline 2. Reading Speed & 51.0 & 138.0 & 99.68 & 17.7 & -.085 & -.250 \\
\hline 3. Word & 90.2 & 100.0 & 96.23 & 2.43 & -.588 & -.431 \\
\hline 4. Prosody & 4.00 & 16.00 & 11.94 & 2.93 & -.397 & -.347 \\
\hline 5. Reading & 7.00 & 24.00 & 17.37 & 3.94 & -.288 & -.466 \\
\hline
\end{tabular}

The attention level scores of the 132 participants are shown in Table 1 . The lowest score was 80 , and the highest score was 120 . The average attention level was 108.128 , while the standard deviation (SD) was 9.72.

The lowest reading speed was 51 , and the highest reading speed was 138 . The standard deviation (SD) of reading speed was 17.78 , and average reading speed was 99.68 . The data show that the students' reading speeds were significantly different from each other.

The lowest word recognition score of the students was 90.27 , and the highest score was 100 . The average word recognition score was 96.23 , and its standard deviation (SD) was 2.43 . The study concluded that the difference between word recognition levels was low, and the students were similar to each other in this respect. It also concluded that the good readers had a high average word recognition level.

The highest prosodic score was found to be 16, which indicated that the students were slightly different. The students' average prosody score was 11.94, and its standard deviation (SD) was 2.93 .

The lowest reading comprehension score was 7 , while the highest score was 24 . The average score was 17.37 , and the standard deviation (SD) was 3.94, which again indicated that the students were slightly different.

Correlation analysis was conducted to see the relationships between the variables. Table 2 shows the correlations between the variables. 
Table 2. Correlations Between Variables

\begin{tabular}{|c|c|c|c|c|c|}
\hline Variables & 1 & 2 & 3 & 4 & 5 \\
\hline 1. Attention & 1.00 & & & & \\
\hline 2. Reading Speed & $.47 * *$ & 1.00 & & & \\
\hline 3. Word Recognition & $.34 * *$ & $.54 * *$ & 1.00 & & \\
\hline $\begin{array}{c}\text { 4. Prosody } \\
\text { 5. Reading } \\
\text { Comprehension }\end{array}$ & $.47^{* *}$ & $.65^{* *}$ & $.60 * *$ & 1.00 & \\
\hline
\end{tabular}

Note: $* * \mathrm{p}<.01$

According to Table 2 , there was a significantly $(p<.01)$ positive relationship between attention, reading comprehension and reading fluency. Thus, the higher the attention level, the higher the reading fluency and reading comprehension. According to these results, attention was most closely associated with the reading speed and prosody variables $(\mathrm{r}=.47, \mathrm{p}<.01)$. The highest positive association among the variables was observed between prosody $(r=.65$, $\mathrm{p}<.01$ ) and reading speed, and the lowest positive relationship was observed between attention $(r=.24, p<.01)$ and reading comprehension.

Table 3 shows the results of a simple regression analysis of the extent to which attention predicted reading fluency.

Table 3. The Results of a Simple Regression Analysis of the Extent to Which Attention Predicts Reading Fluency and Reading Comprehension

\begin{tabular}{|c|c|c|c|c|}
\hline Predictor & $\boldsymbol{B}$ & $\boldsymbol{S H}$ & $\boldsymbol{\beta}$ & $\boldsymbol{R}^{2}$ \\
\hline Reading Speed & .86 & .09 & $.47^{* * *}$ & .22 \\
\hline Word & .08 & .01 & $.34 * * *$ & .11 \\
\hline Prosody & .14 & .01 & $.47^{* * *}$ & .22 \\
\hline Reading & .01 & .02 & $.24 * *$ & .06 \\
\hline
\end{tabular}

$* * * \mathrm{p}<.001, * * \mathrm{p}<.05$

Table 3 shows that attention accounted best for reading speed and prosody. The attention of students with grade level adequate reading skills accounted for $22 \%$ of both reading speed and prosody, for $6 \%$ of reading comprehension and for $11 \%$ of word recognition. Moreover, attention predicted reading speed and prosody $(\beta=.47, \quad p<.001)$, word recognition $(\beta=.34, p<.001)$ and reading comprehension $(\beta=.24, p<.05)$, respectively and in descending order at a significantly positive level.

\section{Results and Discussion}

This research concluded that attention in good readers who had grade level adequate reading skills is significantly associated with reading speed, prosody, reading comprehension and word recognition. This is because effective reading includes reading, comprehension and reading fluency components. Good readers pay close attention to these factors. Attention's relationship with reading speed and prosody was higher than it was with word recognition and comprehension. The readers who acquired grade level adequate reading skills utilized attention for reading speed and prosodic reading rather than for comprehension and word recognition. This was because good readers had acquired grade level adequate reading skills, and they were reading efficiently without the need for help. At this point, students can pay attention to the variables with which they have most difficulty. Lai, Benjamin, Schwanenflugel and Kuhn [13] reported that good readers-meaning fluent readers-pay attention to appropriate stresses, intonation and pauses when reading.

Good readers' attention significantly affected reading speed, prosody, word recognition and comprehension, respectively. The attention of students with grade level adequate reading skills accounted best for reading speed and prosody. This was because the time the readers with automatized reading used while implementing their reading skills was important. They tried to read the highest number of words within a specified period by understanding them. Attention accounted for prosody afterwards. Good readers paid attention to voice, intonation and stress when reading, and they read effectively. However, attention's ability to account for word recognition and reading comprehension had a significant, but quite a low percentage. This was because word recognition and reading comprehension were among the basic prerequisite steps of the reading process for good readers. Satisfactory reading cannot be achieved without these factors. Since individuals with grade level adequate reading skills had surpassed these steps, they remained in the background compared to the points to which they paid attention. Previous studies have shown that poor readers were more focused and used their attention for word recognition and comprehension [22, 14]. Previous studies have also shown that poor readers recognize written texts more slowly than good readers and take longer to understand them [8]. Readers with poor word recognition had trouble controlling their attention, which affected their reading skills negatively [4]. Poor readers needed attention more in the stage of word recognition.

To improve readers' prosodic skills and reading speed, activities that increase their attention in class are needed. Here, teachers and parents have great responsibilities. They should arrange activities to help them focus their attention by playing at the beginning of the course or when they feel they were distracted. Similarly, parents should continue these processes in the home environment with the cooperation of teachers.

Improving students' prosodic skills at the school age is quite important. Doing so helps students express themselves better and understand what they read more easily. Increased emphasis should be placed on this important concept and this concept should be improved, particularly for readers with 
automatized reading who do not make reading mistakes. Therefore, teachers should read aloud to their students to serve them as models of prosodic reading. They should also monitor the oral reading skills of their students and give them meaningful feedback. The reading practices implemented in the classroom should be audiotaped, and students should listen to them and notice their mistakes. They will become aware of issues they need to be careful about in the prosodic reading process. Performing similar activities at school will contribute to higher achievement.

In addition to prosodic reading, good readers pay attention to automatization. Efforts should be made to ensure that the number of words read per minute is in the norms appropriate for the grade level. Simultaneous and mutual improvement of these two skills will help students have appropriate reading skills, be prosodic and understand what they read.

Finally, further research is needed to describe the relationship between reading and attention. The relationships tested in this research can be reconsidered for disadvantaged groups such as poor readers and readers with reading difficulties. New variables can be added to the research, and their relationships to attention can be examined in different contexts.

\section{Appendix}

\section{Annex 1}

\section{The Winter Season}

There was a farmer who continuously complained about the winter weather. He always thought that it had snowed and coated everything before he completed his summer work. Beyond just thinking, he got very angry when he went outside and saw the snow, and said, "The dead of cruel winter! You are the ugliest of the seasons! You blow in and cause me to leave my work unfinished. Would it not be better if you came later, and I could finish my work? Then, at least, let us know when you are coming."

In fact, the farmer's thoughts were not quite right because he always dragged his feet, saying, "Anyhow, it is still warm."

One day, the farmer cursed the winter as he always did. He heard a voice and was startled. It said, "That's enough! I am the winter about whom you complain every day!"

The farmer looked around, but he could not find where the voice came from. At first, he thought that someone was playing a joke on him, but the voice he had heard was too powerful to be a mere human voice. He cocked his ears more. The voice said, "Look at me, my friend! That's enough! I am fed up with your complaints. Due to your laziness, you cannot complete your job before the deadline, then you accuse me of it. You are not an optimistic person. Beyond merely disturbing me, you make yourself and the people around you unhappy. Every fall, I send a messenger and announce when I will arrive, but you do not get the message. Next fall, I will send messengers again and announce when I will arrive. Try to see and hear them. Then, don't talk too much, okay?"

\section{The Original Version of the Annex 1}

\section{Kış Mevsimi}

Bir çiftçi sürekli olarak, kış mevsiminin habersiz geldiğinden şikâyet edip dururmuş. Yazdan kalan işlerini bitiremeden, karların yağıp her şeyin üzerini kapladığını düşünürmüş. Düşünmekle kalsa iyi, dışarı çıkıp da karları görünce çok kızar ve şöyle dermiş:

"Ey zalim kara kış! Sen mevsimlerin en çirkinisin! Habersizce gelip işlerimi yarım bıraktırıyorsun. Biraz daha geç gelsen de, şu işlerimi bitirsem olmaz mı? Bari hiç olmazsa geleceğini haber ver..."

Oysa çiftçi bu düşüncelerinde pek de haklı değilmiş. Çünkü sürekli olarak; "Nasıl olsa havalar henüz sıcak" diyerek işlerini ağırdan alırmış.

Bir gün çiftçi, her zamanki gibi kışa lanetler okuyormuş. Birden bir ses duyup irkilmiş. "Yeter artık!" diyormuş ses. "Ben senin her gün söz saydığı̆ kış mevsimiyim!"

Çiftçi sağa sola baktığı halde sesin geldiği yeri bulamamış. Birisinin kendisine şaka yaptığını zannetmiş önce. Fakat bir insan sesi olmayacak kadar etkili bir sesmiş duyduğu. Daha bir kulak kabartmış. "Bak arkadaş!" diyormuş ses. "Bıktım senin şikâyetlerinden. Tembelliğin sebebiyle işlerini yetiştiremiyor, sonra da beni suçluyorsun. Hiç iyimser bir insan değilsin. Beni rahatsız ettiğin yetmiyormuş gibi, kendini ve çevreni de mutsuz ediyorsun. Her sonbahar mevsiminde birkaç haberci yollayıp geleceğim zamanı bildiriyorum. Ama senin bunları gördüğün mü var. Önümüzdeki sonbahar yine haberciler yollayıp geleceğim zamanı bildireceğim. Onları görmeye ve duymaya çalış. Sonra da fazla konuşma, tamam mı?"

\section{REFERENCES}

[1] Adsız, E. (2010). İlköğretim çağındaki öğrencilerde düzenli yapılan sporun dikkat üzerine etkisinin araştırılması.YükseklisansTezi, EgeÜniversitesi, İzmir.

[2] Akyol, H. (2013). Türkçe ilkokuma yazmaöğretimi. Ankara: Pegem.

[3] Alloway, T.,Wootan, S. \& Deane, P. (2014). Investigating working memory and sustained attention in dyslexic adults. International Journal of Educational Research, 67, 11-17.

[4] Arrington, C. N. (2012). The contribution of attentional control and working memory to reading comprehension and decoding. Master Thesis, University of Houston, Houston.

[5] Chen, C., Huang, S. (2014). Web-based reading annotation system with an attention-based self-regulated learning mechanism for promoting reading performance. British Journal of Educational Technology, 45(5), 959- 980. 
[6] Chenault, B., Thomson, J., Abbott, R. \& Berninger, V. (2006). Effects of prior attention training on Child dyslexics' response to composition instruction. Developmental neuropsychology, 29(1), 243-260.

[7] Creswell, J. (2012). Educational Research Planning, Conducting and Evaluating Quantitative and Qualitative Research. Boston: Pearson.

[8] Driver, J. (2001). A selective review of selective attention research from the past century. British Journal of Psychology, $92,53-78$

[9] Harris, A., Sipay, E. (1990). How to increase reading ability. New York: Longman.

[10] Karaduman, D. (2004). Dikkat toplama eğitim programının ilköğretim 4.ve 5. Sinıf öğrencilerinin dikkat toplama düzeyi, benlik algısı ve başarı düzeylerine etkisi. Doktora Tezi, Ankara Üniversitesi, Ankara.

[11] Karasu, M. (2013). Diyaloğa dayalı öğretim stratejilerinin okuma tutum ve becerilerini geliştirmeye etkisi. DoktoraTezi, Gazi Üniversitesi, Ankara.

[12] Kaymak Özmen, S. (2006). Dikkat toplama becerisini geliştirici etkinlikler- okulöncesi. Ankara: Anı.

[13] Lai, S.A., Benjamin, R.G., Schwanenflugel, P.J. \&Kuhn, M.R. (2014). The longitudinal relationship between reading fluency and reading comprehension skills in second-grade children. Reading \&Writing Quarterly, 30 (2), 116-138.

[14] Miller, A. C., Compton, D., Kearns, D. Zhang, W., Yen, L., Patton, S. \& Kirchner, D. (2014). Behavioral attention: a longitudinal study of whether and how it influences the development of word reading and reading comprehension among at-risk readers. Journal of Research on Educational Effectiveness, 7, 232-249.

[15] Millî Eğitim Bakanlığı (2005). İlköğretim Türkçe dersi (1-5. sınıflar) öğretim program ve kılavuzu. Ankara: Ders Kitapları Müdürlüğü Basımevi.

[16] Rabiner, D., J.D. (2000). Early attention problems and children's reading achievement: a longitudinal investigation. Journal of the American Academy of Child and Adolescent Psychiatry, 39(7),859- 867.

[17] Reynolds, M. \& Besner, D. (2006). Reading aloud is not automatic: Processing capacity is required to generate a phonological code from print. Journal of Experimental Psychology: Human Perception and Performance, 32, 13031323.

[18] Sarter, M., Givens, B., \& Bruno, J. P. (2001). The cognitive neuroscience of sustained attention: Where top-down meets bottom-up. Brain Research Reviews, 35, 146- 160.

[19] Schunk, D. (2011). Learning theories an educational perspective (M. Şahin, Çev.). Ankara: Nobel.

[20] Sesma, H. W.,Mahone, E. M., Levine, T., Eason, S. H., \& Cutting, L. E. (2009). The contribution of executive skills to reading comprehension. Child Neuropsychology, 15, 232-246.

[21] Smallwood, J., Mc Spadden, M., \& Schooler, J. W. (2008). When attention matters: The curious incident of the wandering mind. Memory \&Cognition, 36(6), 1144-1150.

[22] Stern, P. \& Shalev, L. (2013). The role of sustained attention and display medium in reading comprehension among adolescents with ADHD and without it. Research in Developmental Disabilities, 34, 431-439.

[23] Tunç, A. (2013). Golf sporu yapan çocukların dikkat düzeylerinin incelenmesi. Yüksek Lisans Tezi, Selçuk Üniversitesi, Konya.

[24] Unsworth, N., Redick, T., Lakey, C., \& Young, D. (2010). Lapses in sustained attention and their relation to executive control and fluid abilities: An individual differences investigation. Intelligence, 38, 111-122.

[25] Wager, T. D., Jonides, J. \& Reading, S. (2004). Neuroimaging studies of shifting attention: a meta-analysis. NeuroImage, 22, 1679-1693.

[26] Wolf, M. \& Katzir-Cohen T. (2001). Reading fluency and its intervention. Scientific Studies of Reading.211-238.

[27] Yıldız, M., Yıldırım, K., Ateş, S., Çetinkaya, Ç. (2009). An evaluation of the oral reading fluency of 4th graders with respect to prosodic characteristic. International Journal of Human Sciences, 6 (1), 353-360.

[28] Yıldız, M. (2013). Okuma motivasyonu, akıcı okuma ve okuduğunu anlamanın beşinci sınıf öğrencilerinin akademik başarılarındaki rolü. Turkish Studies, 8(4), 1461-1478. 